\title{
A espetacularização da figura de Chico Xavier e a doutrina Espírita na narrativa midiática 'Chico Xavier'
}

\author{
Aline Torres Sousa Carvalho* \\ Guilherme Jorge de Rezende**
}

\section{Resumo}

O objetivo deste trabalho é analisar o processo de espetacularização da figura de Chico Xavier e da doutrina Espírita na narrativa midiática Chico Xavier, de Daniel Filho. A metodologia consta de pesquisa bibliográfica e descrição e análise de excertos do filme, nos quais são observados, a partir da transcrição das falas e da identificação de videogramas, os mecanismos utilizados na inserção de Chico Xavier e da doutrina Espírita na esfera do espetáculo midiático. A partir da articulação entre os fundamentos teóricos e as reflexões resultantes da análise, verificamos a consolidação da representação de Chico Xavier como um herói olimpiano da cultura de massa contemporânea.

Palavras chave: Chico Xavier. Indústria cultural. Celebridades. Espetáculo. Espetacularização.

The spectacularization of the figure of Chico Xavier and of the Spiritist doctrine in the mediatic narrative 'Chico Xavier' Abstract

The objective of this paper is to analyze the process of spectacularization of the figure of Chico Xavier and of the Spiritist doctrine in the mediatic narrative Chico Xavier, by Daniel Filho. The methodology is a bibliographic research and

* Doutoranda no Programa de Pós-Graduação em Estudos Linguísticos, do Departamento de Letras, Artes e Cultura da Universidade Federal de Minas Gerais, Belo Horizonte-MG, Brasil.E-mail: alinetorres_letras@yahoo.com.br ** Professor doutor do Programa de Mestrado em Letras, do Departamento de Letras, Artes e Cultura da Universidade Federal de São João del-Rei, São João Del Rei-MG, Brasil. E-mail: gjrezende@uai.com.br 
a description and analysis of the movie excerpts, where are observed, from the transcript of the speeches and the identification of frames, the mechanisms used in the insertion of Chico Xavier and of the Spiritist doctrine in the sphere of the mediatic spectacle. Based on the articulation between the theoretical foundations and the reflections resulting from the analysis, we see the consolidation of the representation of Chico Xavier as an olympian hero of the contemporaneous mass culture.

Keywords: Chico Xavier. Cultural industry. Celebrities. Spectacle. Spectacularization.

\section{La espectularidad de la figura de Chico Xavier y la doctrina Espirita en la narrative mediática 'Chico Xavier' \\ Resumen}

El objetivo de este trabajo es el de analizar el proceso de espectacularidad de la figura de Chico Xavier y de la doctrina Espirita en la narración mediática Chico Xavier, de Daniel Filho. La metodología consta de investigación bibliográfica y descripción y análisis de extractos de la película en las cuales son observados, a partir de la transcripción de las conversaciones y de la identificación de fotogramas los mecanismos usados en la inserción de Chico Xavier y de la doctrina Espirita en la esfera del espectáculo mediático. A partir de la articulación entre los fundamentos teóricos y de las reflexiones resultantes del análisis, constatamos la consolidación de la representación de Chico Xavier como un héroe olímpico de la cultura de masa contemporánea.

Palabras chaves: Chico Xavier. Industria cultural. Celebridades. Espectáculo. Espectacularidad.

\section{Introdução}

"O que é bom aparece. O que aparece é bom". A frase de Debord (1997, p.16-17) sintetiza um dos grandes objetos de desejo na contemporaneidade: a visibilidade. A TV, a internet, as revistas, o cinema constituem um dos principais espaços de valoração da existência humana, em um contexto marcado pelo espetáculo da indústria cultural. Uma das características deste espetáculo é o culto às celebridades, aos olimpianos, segundo o conceito de Edgar Morin (1987). As celebridades lançadas pela TV, pela internet, por revistas, são os ícones da sociedade. Elas representam um ideal de vida e lazer, um modelo a ser seguido pelos espectadores. 
Nesse contexto, o objetivo deste trabalho, que é fruto da dissertação intitulada A representação de Chico Xavier como herói virtuoso: uma análise da narrativa midiática Chico Xavier (CARVALHO, 2011), é analisar o processo de espetacularização de Chico Xavier e da doutrina espírita no filme Chico Xavier, de Daniel Filho. Quais são os procedimentos, no filme em questão, utilizados para a espetacularização de Chico Xavier, que ocorre tanto no filme, quanto em âmbito maior (na sociedade na qual a filmografia é produzida)?

Para tanto, realizamos primeiramente uma pesquisa bibliográfica, utilizando como referencial teórico-metodológico autores que versam sobre a Comunicação e a cultura de massa - Adorno e Horkheimer (1986), Guy Debord (1997), Edgar Morin (1987), Rubim (2002). Em seguida, a partir dos conceitos de tais autores, procedemos à análise de excertos do filme, feita a partir da transcrição de falas dos personagens e da identificação de videogramas. Utilizamos como critério para seleção de tais excertos o fato de eles evidenciarem os elementos do processo de espetacularização da figura de Chico Xavier e da doutrina espírita, tais como: sua representação como uma celebridade midiática (ou como um olimpiano da cultura de massa), a representação da inserção da mídia em sua vida, a autorreferencialidade e a operação metalinguística midiáticas.

Consideramos importante salientar que não pretendemos realizar uma análise da narrativa fílmica como um todo, o que demandaria a investigação de outros elementos próprios da linguagem cinematográfica, além dos diálogos e do roteiro.

\section{espetáculo midiático da indústria cultural}

A sociedade na qual as vidas de pessoas se tornam, com frequência, matéria-prima para as produções midiáticas, sejam estas configuradas por filmes, programas de TV ou até mesmo livros, é uma sociedade marcada pelo predomínio das imagens, pela junção dos valores do público e do privado, pela busca da visibilidade. É uma sociedade na qual alguns conceitos merecem ser revisitados, como o de indústria cultural (ADORNO; HORKHEIMER, 1986). 
Conforme Adorno e Horkheimer (1986), os Meios de Comunicação de Massa, atrelados ao capitalismo, transformam a cultura e as próprias subjetividades em mercadorias, submetendo-as aos ditames do capital. Música, dança, teatro e as demais manifestações artísticas tornam-se elementos passíveis de consumo, constituintes de um único sistema, a indústria cultural. "[...] a cultura contemporânea confere a tudo um ar de semelhança. $\mathrm{O}$ cinema, o rádio e as revistas constituem um sistema. Cada setor é coerente em si mesmo e todos o são em conjunto" (ADORNO; HORKHEIMER, 1986, p.113).

Cinema, rádio e revistas constituem um sistema do qual os próprios seres humanos fazem parte, pois são os consumidores, são aqueles a quem tais produtos são destinados. Esse sistema tem como mola motriz o sistema capitalista, de modo que a submissão das produções culturais à técnica traz como consequência principal o esmaecimento das particularidades de cada uma delas, a padronização. Destinadas ao consumo, as produções da indústria cultural devem agradar ao grande público, sendo, nesse sentido, não uma cultura de massa, mas uma cultura produzida para as massas, mais especificamente, para o consumo das massas.

Edgar Morin (1987, p.67), utilizando o termo cultura de massa, analisa a relação entre os produtos oferecidos pelos Meios de Comunicação de massa e a sociedade, passando pela esfera da organização social do trabalho. Para o autor, as configurações do lazer moderno, marcado pelo consumo dos produtos da indústria cultural, têm origem na própria organização do trabalho burocrático e industrial. Nessa organização, os trabalhadores são enquadrados no mercado da economia capitalista como consumidores, de forma que ela deve lhes oferecer não apenas um tempo de repouso e recuperação, mas também de consumo. "Nesse sentido, o lazer é, então, um tempo ganho sobre o trabalho".

No entanto, para o autor, a padronização e a submissão das produções culturais à técnica e à divisão do trabalho não eliminam, necessariamente, a criação, de modo que é "[...] na própria estrutura do imaginário” [...] (MORIN, 1987, p.26) que se encontra a possibilidade da padronização da cultura. Conforme o autor, 
O imaginário se estrutura segundo arquétipos: existem figurinos-modelo do espírito humano que ordenam os sonhos e, particularmente, os sonhos racionalizados que são os temas míticos ou romanescos. (...) A indústria cultural persegue a demonstração à sua maneira, padronizando os grandes temas romanescos, fazendo clichês dos arquétipos em estereótipos (MORIN, 1987, p.26).

Assim, a indústria cultural utiliza padrões já estabelecidos no próprio imaginário humano, o que possibilita os processos de identificação e projeção dos indivíduos. Há uma espécie de estrutura mítica que rege todas as narrativas e de personagens-padrões nos quais os seres humanos encontram modelos para suas vidas reais.

Conforme Morin (1987), a indústria cultural insere as manifestações humanas, artísticas e culturais na divisão social do trabalho, fazendo com que cada um seja responsável apenas por parte da produção (os roteiristas, os cenaristas, os operadores, os atores etc.). Mas esse processo não significa, por si só, a desindividualização da obra.

A divisão do trabalho, porém, não é, de modo nenhum, incompatível com a individualização da obra: ela já produziu suas obras-primas no cinema, se bem que, efetivamente, as condições ideais da criação sejam aquelas em que o criador possa assumir, ao mesmo tempo, as diversas funções industrialmente separadas (a idéia, o cenário, a realização e a montagem). A padronização em si mesma não ocasiona, necessariamente, a desindividualização [...] (MORIN, 1987, p.31).

Vinte anos após os escritos dos frankfurtianos Adorno e Horkheimer (1986), Debord (1997, p.13) atenta, em sua obra A sociedade do espetáculo, para a transferência das vivências diretas dos indivíduos para a posição de espectadores, de consumidores passivos de imagens. Desse modo, as próprias relações sociais passam a ser mediadas por imagens. Essa transferência ocorre a partir da separação entre o que é real e o que é representação: "toda a vida das sociedades nas quais reinam as modernas condições de produção se apresenta como uma imensa acumulação de espetáculos. Tudo o que era vivido diretamente tornou-se uma representação".

De acordo com Debord (1997), na sociedade capitalista, em vez de viverem segundo a realidade, os indivíduos vivem confor- 
me imagens representações da realidade. Há, nesse sentido, um predomínio das imagens, da representação, sobre a realidade. A imagem torna-se autônoma, o indivíduo torna-se alienado e, mergulhado na representação, se esquece de si mesmo. A realidade torna-se, então, uma pseudorrealidade, e o mundo, um objeto de contemplação. "Quando o mundo real se transforma em simples imagens, as simples imagens tornam-se seres reais e motivações eficientes de um comportamento hipnótico" (DEBORD, 1997, p.18). Nesse contexto, o ser humano é aquele que olha, que contempla, que assiste ao que deveria ser vivido, em uma sociedade na qual impera a produção e o consumo de imagens midiáticas, de eventos culturais, de mercadorias.

A visão de Debord (1997) e a de Adorno e Horkheimer (1986) serve de ponto de partida para muitas reflexões, não esgotadas até o momento. Esses autores atribuem ao espetáculo um sentido sempre negativo. Muitos estudiosos consideram esse ponto de vista inadequado, já que a configuração da mídia mudou radicalmente.

Para Rubim (2002), o espetáculo sempre existiu nas sociedades, não sendo, pois, um elemento intrinsecamente capitalista, tal como defende Debord (1997). Para compreender o sentido do espetáculo, Rubim (2002) busca, primeiramente, elucidar um conceito para este:

Spectaculum, raiz semântica (latina) de espetáculo, tem como significado tudo que atrai e prende o olhar e a atenção. Recorrendo ao dicionário, três outras acepções de sentido podem ser enumeradas: representação teatral; exibição esportiva, artística etc. e cena ridícula ou escândalo. (RUBIM, 2002, p.10).

Assim, no cerne do conceito de espetáculo, encontra-se uma relação entre evento e espectador, entre aquele que se exibe e aquele que olha, de modo que tal relação seja marcada pelo vislumbre. $\mathrm{O}$ que se exibe, ou é exibido, prende o olhar, chama a atenção e fascina quem assiste a ele. A sedução é, então, um elemento fundamental do espetáculo.

Outras duas premissas do espetáculo são o caráter necessariamente público e sua ligação à esfera do sensacional, do surpre- 
endente (RUBIM, 2002). Se um evento ou um personagem busca atrair o olhar, ele o deve fazer mediante espectadores, o que faz necessário que tal exibição ocorra em um lugar apropriado. $\mathrm{O}$ que é exibido ao público, para seduzi-lo, deve ser algo extraordinário, de maneira que haja uma ruptura com a vida ordinária das pessoas.

O que se pode constituir espetáculo, o que causa maravilhamento, é determinado social e historicamente. Nas diversas sociedades e culturas e em diferentes circunstâncias, existem acontecimentos que, por suas características e pela maneira com a qual os indivíduos lhes dão significado, podem ser denominados espetáculos. Em diferentes tempos e lugares, diferentes culturas produzem espetáculos à sua maneira, de modo que, na sociedade atual, a mídia representa o elemento norteador da construção do que é considerado espetacular. Para além de palcos e ruas, o espaço virtual apresenta-se como uma das principais arenas de exibição de espetáculos, que são produzidos pela TV, pelo cinema, pelas revistas de fofoca, pela internet. E nessa conjuntura social, pessoas tornam-se personalidades, celebridades, e suas vidas são espetacularizadas.

Como o espetáculo é produzido social e culturalmente, a partir do acionamento do maravilhoso, ele ocorre segundo um processo denominado espetacularização, termo que pode ser definido como “(...) um processo, através do qual, pelo acionamento de dispositivos e recursos dados, produz-se o espetáculo. Ou melhor, o espetacular" (RUBIM, 2002, p.16). Assim, os espetáculos são configurados a partir de fatores que o enquadram como tal. Tais espetáculos podem ser midiáticos ou não, podem estar relacionados às esferas política, religiosa, pessoal. Podem ser constituídos a partir da exploração de vidas privadas. São, contudo, produções que, em determinados contextos sociais e discursivos, são capazes de encantar.

[...] a espetacularização aciona, simultaneamente, uma multiplicidade de dimensões - emocionais, sensoriais, valorativas e também cognitivas - para fabricar e dar sentido ao espetacular. Nessa perspectiva, o espetacular deve ser sempre encarado como construção social e discursiva (RUBIM, 2002, p.16). 


\section{Os olimpianos na cultura de massa}

Nos espetáculos criados pela mídia, ganham destaque as celebridades lançadas pela TV, por revistas e pela internet. A mídia cria a cada dia novas personalidades, novos olimpianos, cujas vidas devem servir de modelos aos espectadores. "(...) o ideal da cultura do lazer, sua obscura finalidade, é a vida dos olimpianos modernos, heróis do espetáculo, do jogo e do esporte (MORIN, 1987, p.75”). Os olimpianos são os ícones da atual sociedade, midiatizados e espetacularizados tanto por papéis que realizam em novelas e filmes, quanto por suas atividades no âmbito da realidade. Suas vidas reais e imaginárias correspondem ao ideal de perfeição, ditando modelos a serem seguidos por homens e mulheres de diferentes faixas etárias e classes sociais.

No encontro do ímpeto do imaginário para o real e do real para o imaginário, situam-se as vedetes da grande imprensa, os olimpianos modernos. Esses olimpianos não são apenas os astros de cinema, mas também os campeões, príncipes, reis, playboys, exploradores, artistas célebres, (...) (MORIN, 1987, p.105).

Assim, astros do cinema e da TV, jogadores de futebol, cantores, políticos convivem com os sujeitos "comuns" da sociedade do espetáculo, mediados pela película da tela (da TV, do cinema ou do computador), mas pautando em grande medida suas vidas.

Com o objetivo de entreter e de capturar adeptos a sua doutrina, a cultura de massa, ou cultura do lazer, busca divulgar a vida dos atuais olimpianos, muitas vezes em detrimento de assuntos sociais e/ou políticos. A mídia deve manter os espectadores informados sobre as vidas de suas celebridades, em um processo que reforça a distância entre aqueles que vivem de maneira "ativa" (dançam, flertam, seduzem) e os espectadores, "menos ativos", que contemplam os olimpianos. Esse processo, ao mesmo tempo em que mantém a contraposição entre olimpianos e pessoas comuns, convida os sujeitos da sociedade do espetáculo a viverem conforme o modelo das vedetes midiáticas. É instaurada uma dualidade que atiça o espectador, mas nega 
sua realização, uma vez que os olimpianos devem ser seguidos, mas nunca alcançados.

Os novos olimpianos são, simultaneamente, magnetizados no imaginário e no real, simultaneamente, ideais inimitáveis e modelos imitáveis; sua dupla natureza é análoga à dupla natureza teológica do herói-deus da religião cristã: olimpianas e olimpianos são sobre-humanos no papel que eles encarnam, humanos na existência privada que eles levam. A imprensa de massa, ao mesmo tempo que investe os olimpianos de um papel mitológico, mergulha em suas vidas privadas a fim de extrair delas a substância humana que permite a identificação (MORIN, 1987, p.106-107).

Nesse sentido, os atuais ídolos da sociedade são seres ao mesmo tempo reais e imaginários. A mídia lhes confere o papel mitológico de novos deuses, os quais fornecem aos espectadores modelos de comportamento e conduta.

\section{O contexto de produção do filme 'Chico Xavier'}

O processo de espetacularização de Chico Xavier e da doutrina Espírita compreende elementos exteriores ao próprio filme, elementos relacionados ao contexto de sua produção e à exploração da figura do médium em um âmbito maior, mais generalizado. Trata-se de um contexto social marcado por uma forte tendência à espetacularização, ao culto às celebridades, à criação de heróis da mídia. Desse modo, a própria produção do filme aponta para a espetacularização, uma vez que ocorre em um amplo contexto de exploração midiática da história de Chico Xavier e da doutrina Espírita.

No ano de 2010, ano do centenário de nascimento de Chico Xavier, foi produzido, além do filme que conta sua vida, o filme Nosso Lar, de Wagner de Assis; e, em 2011, o filme As mães de Chico Xavier, de Glauber Filho, ambos baseados em obras psicografadas por Chico Xavier. Em 2003, já havia sido produzida a biografia As vidas de Chico Xavier, de Marcel Souto Maior, na qual Chico Xavier foi baseado.

A figura de Chico Xavier e a doutrina Espírita foram, e ainda têm sido, muito exploradas pela mídia, o que aumenta a venda de livros e a produção de filmes do gênero. Bezerra de Menezes - o 
diário de um espírito (2008), de Glauber Filho, protagoniza a vida do médico e político que foi um dos grandes representantes do espiritismo no país. E há, ainda, a mais recente produção, que é $O$ Filme dos Espíritos, de André Marouço e Michel Dubret, baseado na obra de Alan Kardec, O Livro dos Espíritos.

Na época do lançamento do filme Chico Xavier, Daniel Filho (o diretor do filme) e os principais atores participaram de vários programas de TV para falar sobre o médium e foram pauta de jornais impressos e de sites. Apenas como exemplificação, podemos citar: Nelson Xavier (Chico Xavier) e Marcel Souto Maior (autor da biografia na qual o filme foi baseado) participaram do programa Mais Você (Rede Globo), falando sobre o filme. Daniel Filho (o diretor) foi entrevistado no programa Bastidores (Multishow). Marília Gabriela conversou com Ângelo Antônio (que interpretou o médium em sua fase de juventude) e Nelson Xavier em Marília Gabriela Entrevista (GNT), Christiane Torloni (Glória) falou sobre o filme no programa Vídeo Show (Globo).

Assim, a espetacularização da vida do médium e da doutrina Espírita ocorre, também, pela frequência com a qual o assunto é explorado, sendo exibido em diferentes programas, no caso dos exemplos citados, todos de canais pertencentes à Rede Globo de Televisão, já que o filme é uma produção da Globo Filmes. Esse fenômeno caracteriza a sinergia, termo que, na mídia, “(...) descreve como um meio de comunicação pode ser usado para promover a mesma idéia, produto, celebridade ou político em outro meio de comunicação, ambos pertencentes à mesma corporação" (BAGDKIAN, 1993, p.285).

Outra característica do filme que merece ser destacada, em um contexto de espetacularização, é seu elenco, composto por atrizes e atores consagrados na televisão brasileira, no cinema e no teatro. Tony Ramos, Christiane Torloni, Ângelo Antônio, Nelson Xavier, Paulo Goulart, Pedro Paulo Rangel, Cássio Gabus Mendes, Letícia Sabatella, Cássia Kiss e Giulia Gam são as celebridades escolhidas pelo diretor, também famoso, Daniel Filho. Chico Xavier é, nesse sentido, uma produção espetacular, produzida pela indústria cultural e, mais especificamente, pela Globo Filmes, e que tem 
como um dos artifícios para emocionar seu público, a presença de olimpianos, ícones da sociedade atual.

\section{Análise do filme}

Para proceder à nossa análise, é importante destacar que há, no enredo do filme Chico Xavier, uma dupla ficcionalização do médium: uma que corresponde à representação da realidade cotidiana do personagem, e outra que se refere à representação de sua participação em um programa de TV.

O enredo do filme é organizado a partir da participação de Chico Xavier em um programa de entrevistas do qual participou duas vezes, em 1971, o Programa Pinga-Fogo, da extinta TV Tupi. É, portanto, uma produção midiática baseada em outra produção midiática, tratando-se da mídia mostrando ela mesma. Esse aspecto explicita uma das características da espetacularização: a autorreferencialidade midiática.

Em uma sociedade em que impera o espetáculo, é cada vez mais incidente a presença da própria mídia em suas produções, seja por meio da temática (programas cujo objetivo é mostrar celebridades midiáticas, novelas e/ou personagens, que contem a história da emissora), ou por meio da estrutura, quando programas se voltam para a explicitação de sua própria organização (como é o caso do Profissão Repórter, da Rede Globo). Em todos esses casos há um processo de autorreferencialidade, que “(...) se apresenta quando determinado campo utiliza diferenciadas estratégias de ato e discurso para se mostrar, falar de si, explicar seus modos de ser e agir, buscando sua legitimação" (SGORLA; FOSSÁ, 2008, p.4).

Conforme Requena (1999), o discurso televisivo tende a não se referir a outra coisa senão a ele mesmo. A informação cede lugar à publicidade dos programas exibidos na própria emissora ou a programas que dizem respeito a outros programas televisivos. Desse modo, a TV tem em si mesma, um de seus principais assuntos, sendo o espetáculo em estado puro (REQUENA, 1999).

O processo de autorreferência, que ocorre não só na TV, mas na mídia em geral, implica outro fenômeno: a metalinguagem, 
termo que tem origem na Teoria da Comunicação, proposta por Jackobson (2010). O linguista do Círculo Linguístico de Praga teve como um de seus objetos de estudo as funções da linguagem, dedicando-se a compreender com que finalidade as unidades linguísticas eram utilizadas na Comunicação entre um remetente e um destinatário.

A teoria de Jackobson (2010) determina seis fatores constitutivos do ato de Comunicação: 1) o remetente (o codificador); 2) a mensagem; 3) o destinatário (o decodificador); 4) o contexto (a que ou a quem se refere); 5) o código (os signos utilizados para elaborar a mensagem); 6) o contato (canal físico a partir do qual ocorre a Comunicação). "Cada um desses seis fatores determina uma diferente função da linguagem” (JACKOBSON, 2010, p.157).

A função metalinguística, que nos interessa nesse artigo, tem como principal característica o fato de o foco da Comunicação recair sobre o próprio código, de modo que a língua seja utilizada para explicar a si mesma. Um exemplo é quando o locutor explica o sentido de uma palavra proferida ao seu interlocutor; ou o uso das palavras em dicionários e gramáticas.

Em diversas produções midiáticas e, em especial no filme Chico Xavier, o código volta-se para si mesmo. No filme, há a representação dos bastidores do Programa Pinga-Fogo, sua gravação, os movimentos de câmera, as falas dos produtores durante a gravação. Não se trata, pois, de o cinema mostrando seu próprio funcionamento, ou seja, de um filme dentro de um filme; mas, de um produto midiático mostrando o funcionamento de outro produto midiático.

Conforme Andrade (1999), a metalinguagem é um recurso utilizado para revelar as estratégias narrativas usadas pelo cinema e tornar explícito o seu código, remetendo-se à sua própria estrutura. Essa estratégia tem como objetivo criar uma cumplicidade com o público, estabelecer um elo de identificação com o espectador que, diante do funcionamento do cinema, sente-se desvendando um segredo. No caso do filme Chico Xavier, o segredo a ser mostrado são os bastidores do Programa Pinga-Fogo, destacando o modo com o qual o espetáculo é organizado pelos produtores do programa. 
Ao mesmo tempo em que o filme toma a vida de Chico Xavier como objeto do espetáculo, mostra como ocorreu o processo de espetacularização tanto na gravação do Programa Pinga-Fogo, quanto na própria vida do médium. Para analisarmos esse processo, identificamos e destacamos videogramas representativos do mesmo, como veremos mais abaixo.

Conceituamos videograma, a partir de Lochard e Soulages (1993), como uma configuração visual estável, definida pela continuidade dos parâmetros de criação de imagens e dos sujeitos ou objetos filmados. Trata-se de uma unidade de análise e de decomposição do material audiovisual, que representa um instante e dá ideia do todo da cena ${ }^{1}$.

Logo no início do filme sobre Chico Xavier, há uma cena que simboliza, de maneira sintética, a transformação do médium em um olimpiano, processo ocorrido em sua vida real e retratado no filme analisado. Trata-se do momento em que ele está entrando para o auditório no qual o programa seria gravado e é tratado como um ícone da sociedade midiatizada, um ídolo.

\section{EXCERTO 1:}

Chico Xavier atravessa um corredor que dá acesso ao auditório do programa. Muitas pessoas estão a sua espera. Algumas pedem autógrafos, outras tocam no médium, outras lhe dão a mão ou tomam-lhe a mão, beijando-a. Chico Xavier retribui, beijando a mão de um dos fãs e sendo gentil para com eles.

\footnotetext{
${ }^{1}$ Conforme Lochard e Soulages (1993), o videograma é o método mais conveniente de análise do material audiovisual; no entanto, não podemos deixar de ressaltar que, conforme Martin (1963), uma imagem extraída de um filme é um conteúdo estático, que não pode sugerir o movimento o ritmo da narrativa audiovisual. Desse modo, sugerimos ao leitor que queira ter uma maior compreensão de nossa análise assistir ao filme Chico Xavier.
} 
Figura 1 - Chico é tietado na entrada do estúdio

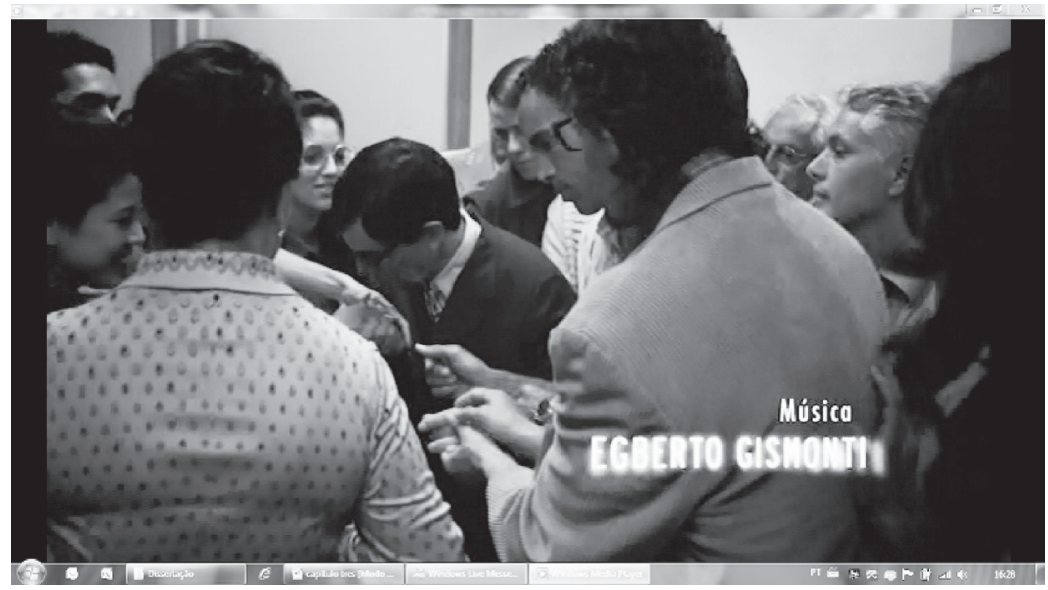

Fonte: Chico Xavier (2010).

No excerto 2, transcrito abaixo, há a chamada e apresentação de Chico Xavier ao público, feita pelo entrevistador Saulo Guimarães, que utiliza palavras, sobretudo as em destaque, que representam enfaticamente a transformação do médium em uma celebridade. Paralelamente, são mostrados os bastidores do programa e a reação dos produtores diante de Chico Xavier.

EXCERTO 2:

S.G.: -- Boa noite senhoras e senhores! Estamos apresentando essa noite mais uma edição do Programa Pinga-Fogo. Conosco, o maior e mais discutido médium brasileiro deste século. Estados Unidos, Inglaterra, França, Itália, Espanha e Portugal já o conheceram. Nascido em 1910, em Pedro Leopoldo, Minas Gerais. Cedo, órfão de mãe, ele psicografou pela primeira vez ainda na juventude. Nos anos 50, Chico foi para Uberaba, onde abriu seu atual centro, o Centro Comunhão Espírita Cristã. Com a venda de três milhões de cópias dos mais de cem livros a ele ditados por seus guias espirituais, ele se dedica a diversas obras sociais.

O: - Deixa ele quieto, lá vem provocação.

SG: - Ele já foi chamado de louco e santo. Fraude? Ou um fenômeno da humanidade? Espíritos existem? A vida acaba após a morte? 
Produtor: -- Orlando, vai estourar essa audiência!

O: - - Vai, vai.

SG: - Conosco, nessa noite, nosso convidado especial Francisco Cândido Xavier. O nosso Chico Xavier.

Figura 2 - Saulo apresenta Chico Xavier

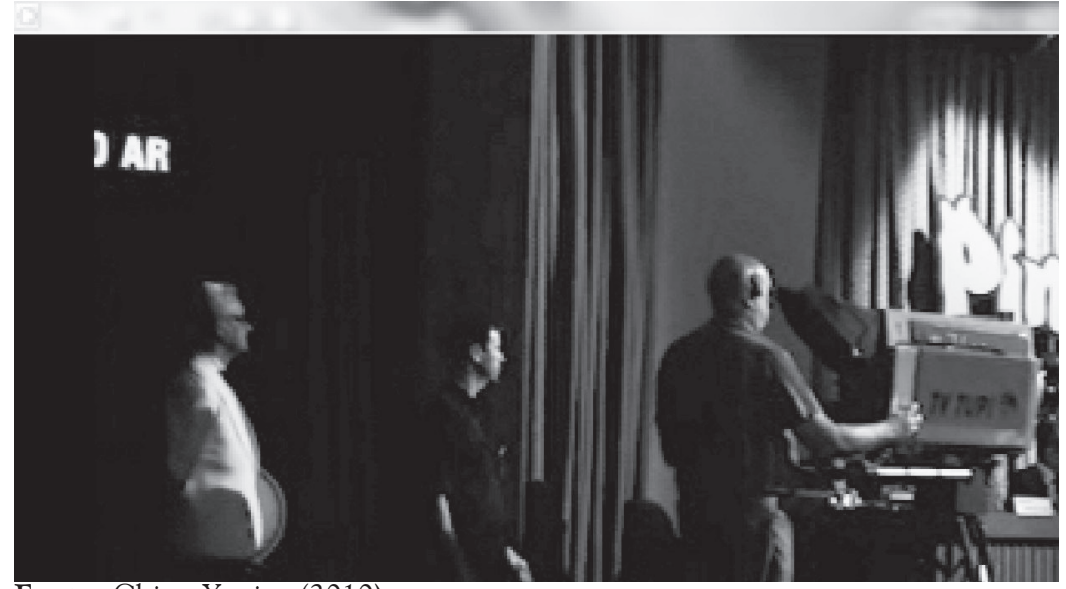

Fonte: Chico Xavier (2010).

Como podemos perceber, Chico Xavier é representado como um grande ídolo da cultura de massa já na chamada do programa. Saulo Guimarães o trata como um "convidado especial", a quem demonstra certa familiaridade, pois o chama de "nosso", mas a quem também oferece provocações, ao dizer que "ele já foi chamado de louco e santo" e ao levantar a hipótese de que ele seja uma "fraude". Provocações, aliás, premeditadas e tecidas pelos produtores do programa, que interferem na cena, deixando claro seu objetivo de despertar o telespectador com a entrevista do médium. O programa, como produto da indústria cultural, deve entreter o público e cativar uma audiência cada vez maior, instigando, para isso, uma polêmica sobre o médium entrevistado.

Há de se destacar, ainda, que durante a fala de Saulo Guimarães, fotos de Chico Xavier e de sua família são mostradas aos telespectadores do programa. Conforme já explicitado, o espetáculo 
é construído pelo acionamento de algo que encanta, que seduz (RUBIM, 2002), de modo que, nesse caso, as fotos de uma família numerosa e humilde fazem parte de um processo que objetiva dar credibilidade à criação do ídolo, que venceu os obstáculos e chegou até aquela situação.

O modo com o qual o espetáculo é organizado pode ser percebido, também, pela representação dos bastidores do Programa Pinga-Fogo, em um processo de autorreferencialidade midiática. Em uma operação metalinguística, o filme, que é um produto da mídia, mostra como ocorre a gravação de outra produção midiática, como o espetáculo é conscientemente produzido, conforme podemos notar abaixo:

\section{EXCERTO 3:}

Quando Chico Xavier responde se sua vida poderia ser considerada uma vida de doação, o produtor Orlando diz:

O: - Corta pra um e vai fechando em zoom.

Figura 3 - Orlando define os movimentos da câmera

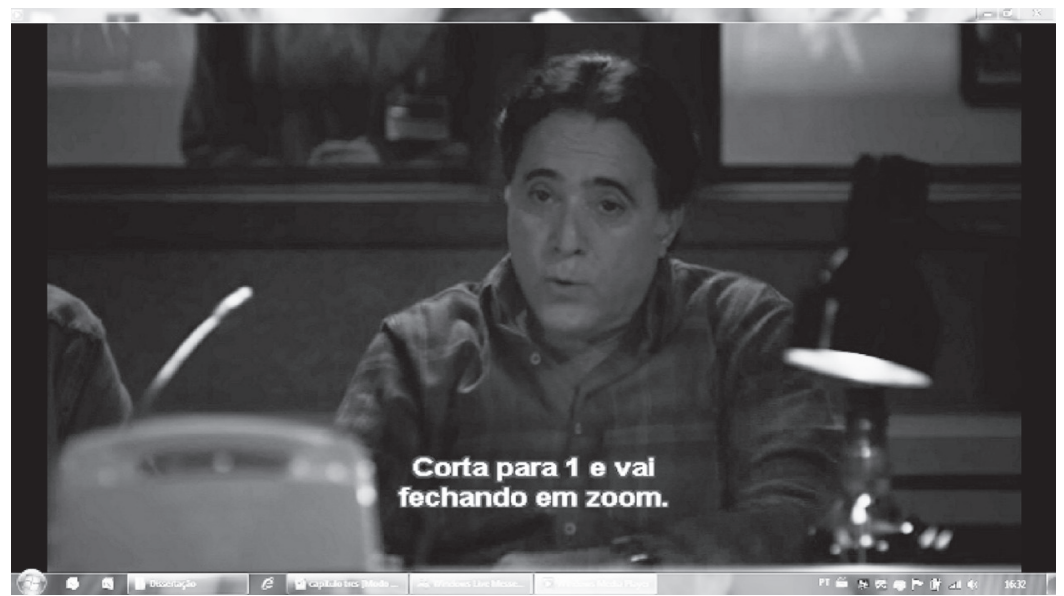

Fonte: Chico Xavier (2010).

Assim, a gravação do programa é mostrada no filme, enfatizando os movimentos da câmera (câmera 1, câmera 2), que 
devem destacar ora Chico Xavier, ora os entrevistadores. No caso do excerto acima, o zoom no médium é uma estratégia para explorar o personagem, suas feições, suas falas. É uma maneira de representá-lo aos telespectadores, uma tentativa de torná-los mais próximos e conquistar audiência.

No programa do qual Chico Xavier participou, o espetáculo é exibido não apenas aos telespectadores, mas a uma plateia presente no auditório, conforme o excerto abaixo:

\section{EXCERTO 4:}

Chico Xavier responde a uma pergunta sobre o uso de drogas em transes:

CX: - Só posso falar por mim e pelo espiritismo. Minha mediunidade se manifestou desde criança. Imagino que minha família nunca tenha feito uso dessas substâncias em mim.

Nesse momento, a plateia sorri e os produtores dizem:

O: -- Me dá a 2 na plateia.

Assistente de produção: -- 2, plateia.

O: - 3 também.

Assistente de produção: -- 3, plateia.

CX: - Tive a curiosidade de comprovar se o estado de alteração provocado por essas substâncias...

O: -- Vai picotando de uma pra outra, devagar. Peraí, devagar, vai, no tempo. Corta 3.

Assistente: - 3 .

CX: — ... sob os cuidados médicos e de Emmanuel, experimentei um alucinógeno.

Assistente: -- Vai dar babado. O cara tomou um ácido e não voltou. Orlando, volta pro Chico.

O: -- É, volta pro Chico.

Nesse trecho, a plateia é enfatizada pela produção do programa para mostrar aos telespectadores sua reação positiva diante da resposta de Chico Xavier. Os produtores vão construindo o espetáculo mostrado na TV, enfatizando o efeito de humor provocado pelo médium no público do auditório e alternando 
com imagens de Chico Xavier e dos entrevistadores. A aprovação da plateia é mais uma estratégia de conquista de audiência, objetivando mostrar o médium como uma personalidade, uma celebridade que possui muitos fãs.

Figura 4 - Orlando pede para filmar a plateia

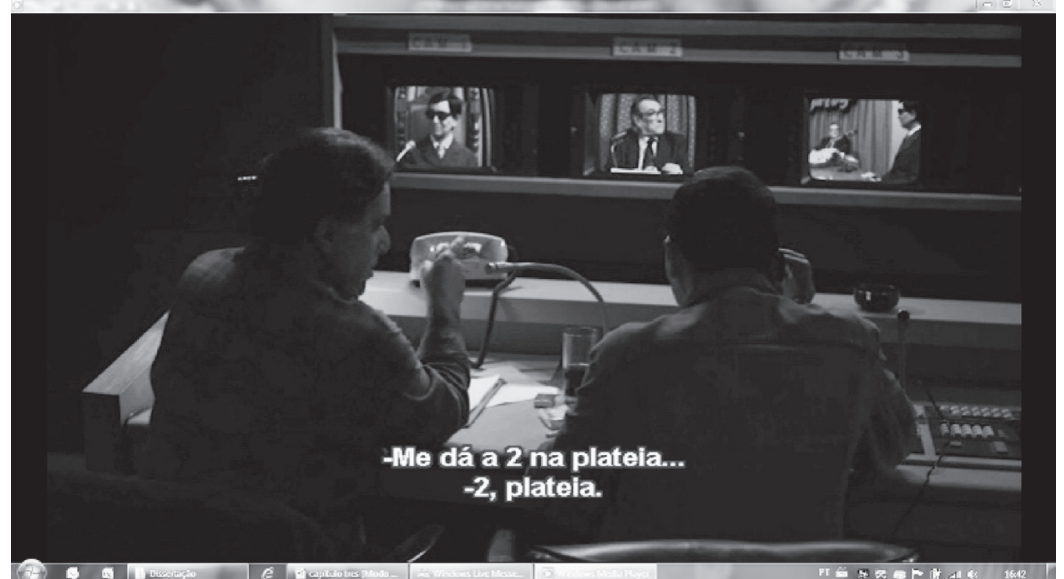

Fonte: Chico Xavier (2010).

Essa celebridade começa a surgir no momento em que a mediunidade de Chico Xavier chega à imprensa e ele ganha visibilidade pela primeira vez. Torna-se mais uma vez explícita a duplicidade da ficcionalização ocorrida no filme. A representação da participação do médium no programa cede lugar à ficcionalização de sua história de vida e de sua inserção na mídia, ou da inserção da mídia em sua vida. É mostrado, no filme, como Chico Xavier foi sendo transformado em um personagem da sociedade espetacularizada. O excerto abaixo mostra Chico Xavier recebendo, de seu irmão, o jornal no qual era um dos assuntos. A reação do médium e de seu irmão é de alegria, uma vez que, até o momento, sua espiritualidade só tinha lhe rendido surras e preconceitos. 
EXCERTO 5:

Chico Xavier acaba de entrar na venda onde trabalha quando chega Zé, seu irmão, com um jornal na mão, dizendo:

Zé: -- Chico! Espia aqui. Espia aqui, Chico! E mostrando o jornal, comemora:

- É de ontem, Chico. Conta tudo, meu irmão, tudinho. Fala das duenças que ocê ajudô a curá, fala dos conselhos. E tem até aquela poesia sua, sô!

Chico, feliz, pega o jornal:

CX: -- A poesia é minha não, Zé, só passou por mim, qui nem vento.

Zé: - Mas né só isso não, meu irmão. Vem cá p’rocê vê, vem.

Os dois saem até a rua e o irmão de Chico Xavier mostra-lhe várias pessoas na porta de sua casa, alguns com o jornal na mão, procurando pelo médium.

Figura 5 - Chico se vê no jornal

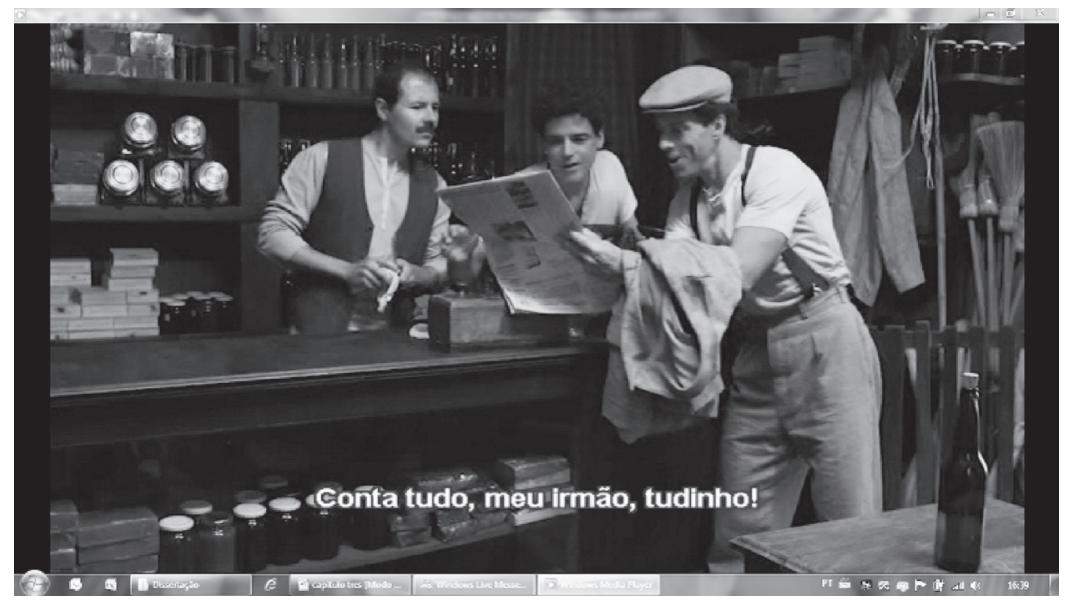

Fonte: Chico Xavier (2010).

Essa reportagem ocasiona uma mudança no cotidiano de Chico Xavier, uma vez que faz dele um dos principais assuntos da cidade de Pedro Leopoldo. A partir de então, o médium se torna cada 
vez mais conhecido em sua cidade e o número de pessoas que o procuram aumenta gradativamente, seja nas sessões espíritas das quais participava, seja em sua casa. Alguns querem conselhos, outros procuram a cura para doenças, outros buscam contato com os mortos. Chico Xavier torna-se uma figura cada vez mais popular, conforme pode ser observado abaixo:

\section{EXCERTO 6:}

Muitas pessoas estão diante do Centro Espírita Luiz Gonzaga, a espera de Chico Xavier, algumas com donativos para lhe oferecer, tais como galinha, verduras e um bode. $\mathrm{O}$ pai de Chico organiza as pessoas em fila, quando o médium chega:

CX: - Que qui aconteceu aqui, pai? Tirô a sorte grande?

Pai: - Milhor qui a sorte grande. Ô filho, agora tá no rumo certo. E eu cá, já sei.

Um senhor aproxima-se de Chico Xavier e diz:

Senhor: - Seu Chico, eu trouxe uma galinha pro sinhor.

Pai: - Agradeço, filho, agradeço.

Figura 6 - Muitas pessoas esperam por Chico

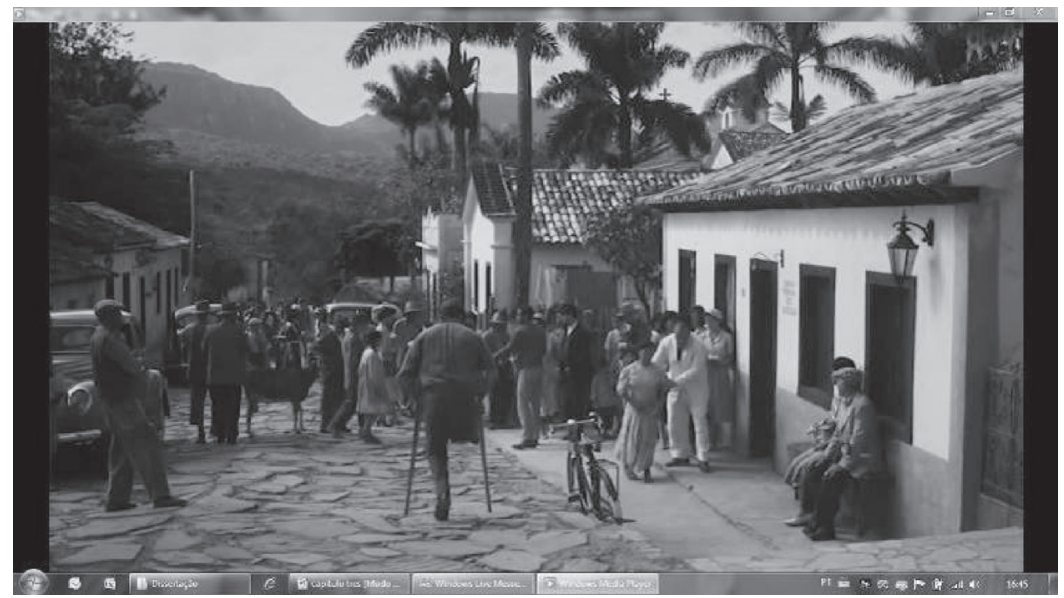

Fonte: Chico Xavier (2010). 
Esse excerto ilustra como a figura de Chico Xavier torna-se, gradativamente, presente no imaginário do povo. Homens e mulheres de diferentes idades ou classes sociais acreditavam em seu poder espiritual, depositando nele esperanças e fazendo de sua figura um ícone. A fama de Chico Xavier traz-lhe uma espécie de idolatria, conforme pode ser percebido no Excerto 6 (seis), quando pessoas lhe oferecem prendas. Uma idolatria que cresce ao longo de sua vida e cujo ápice pode ser observado no início do filme, quando fãs beijam a mão do médium no corredor do estúdio do programa Pinga-Fogo. Entretanto, a presença de Chico Xavier no imaginário do povo revelava-se não apenas pela idolatria, mas também, pela crítica, pela descrença, por acusações de fraudes, como pode ser observado na fala inicial de Saulo Guimarães no início do programa (Saulo Guimarães: -- Ele já foi chamado de louco e santo. Fraude?). Outro excerto que pode ser descrito para exemplificar a polêmica que sua figura gerava no povo é o que representa a Igreja Católica, por meio da figura do padre, interpretado pelo ator Cássio Gabus Mendes, e de outros fiéis, que rejeitavam o médium, conforme podemos ver abaixo:

\section{EXCERTO 7:}

Diante do Centro Espírita Luiz Gonzaga, há muitas pessoas contestando a mediunidade de Chico Xavier. O padre Júlio Maria diz:

Padre Júlio Maria: - Meus filhos! Não entrem aí, por favor. Esta não é a casa de Deus. Quem faz milagre é santo. Não essas pessoas mentirosas feito Chico. O espiritismo é a obra mestra do engano.

Vozes (sobretudo de mulheres) cantam: - Ave, Ave, Ave Maria.

Pe. JM: - É a mais fascinante e bem-sucedida ilusão de Satanás, calculada pra atrair a simpatia dos que tiveram que levar seus queridos à tumba!

E, quando o médium sai do Centro Espírita, o povo o segue até a sua casa, onde param e cantam até que ele entre. 
Figura 7 - Pe. Júlio Maria contesta Chico

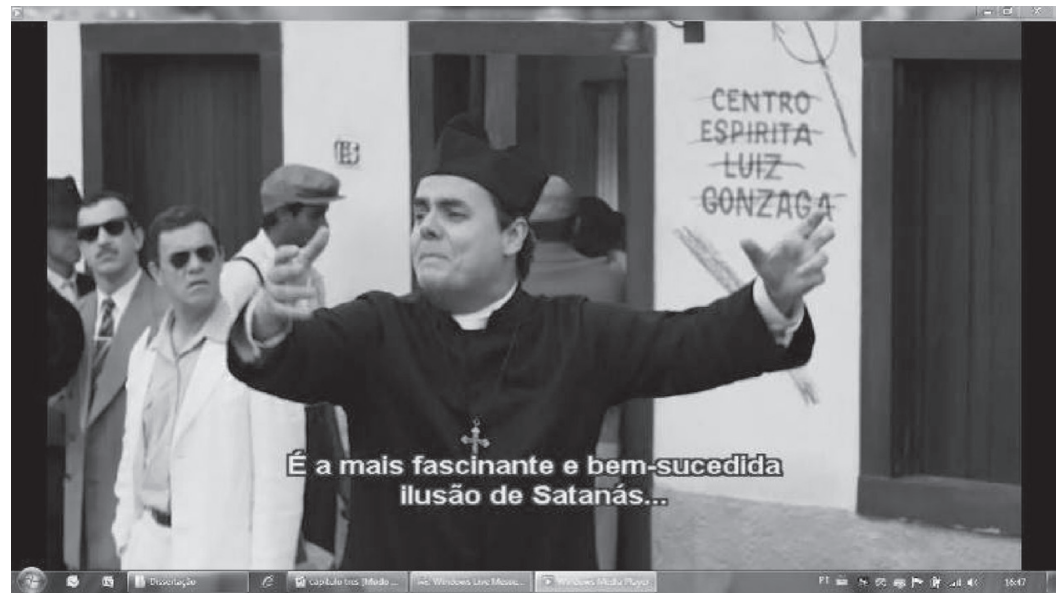

Fonte: Chico Xavier (2010).

O processo de transformação de Chico Xavier em celebridade também está representado no excerto em que Chico Xavier é enganado por David Nasser, repórter e cronista, e Jean Manzon, fotógrafo, da Revista $O$ Cruzeiro. O repórter e o fotógrafo formavam uma das duplas mais consagradas e conhecidas do jornalismo impresso no Brasil. No final dos anos 60, David também se destacou pelas crônicas que escrevia para o programa Diário de um Repórter, na TV Tupi. Tal como a presença de atores famosos no filme, a referência a jornalistas tão célebres enfatiza o caráter espetaculoso do filme (e da vida do médium).

O mesmo trecho do filme representa os objetivos lucrativos da indústria cultural. Nasser e Manzon dizem-se estrangeiros e prometem publicar a entrevista no exterior, mas o que fazem é publicar uma reportagem na revista $O$ Cruzeiro simulando provas de que Chico Xavier fosse uma fraude. Os excertos abaixo ilustram o fato:

EXCERTO 8:

Dois homens aproximam-se de Chico Xavier no final de uma sessão espírita:

CX: - Não quero falar com jornalista agora. 
JV: -- O senhor acertou. Nós somos jornalistas, mas ele é americano, Harry Deam.

HD: - Muito prazer..

JV: -- E eu sou francês, Jacques Vrenel. É pra publicar nos Estados Unidos. Seu processo causou grande interesse por lá. Ninguém vai ver a matéria aqui. New York Times, conhece? Meu colega mesmo nem fala português. Não entende nada.

Os jornalistas acompanham Chico Xavier até sua casa e lhes propõem questões para psicografia. Chico aceita as questões e é fotografado psicografando, o que rende uma reportagem sobre ele na Revista O Cruzeiro, lida por um dos jornalistas:

HD: -- Chico mostra livro dos escritores que depois coincidentemente psicografou. (...) Parece ser um homem que possui uma vida de sacrifício como a dos santos. Entretanto, sua vaidade nas fotos é evidente. E mais importante: nossa entrevista foi fruto de uma farsa. Isso mesmo. Uma farsa. Como Chico Xavier também pode ser.

Figura 8 - Jornalistas festejam reportagem sobre Chico

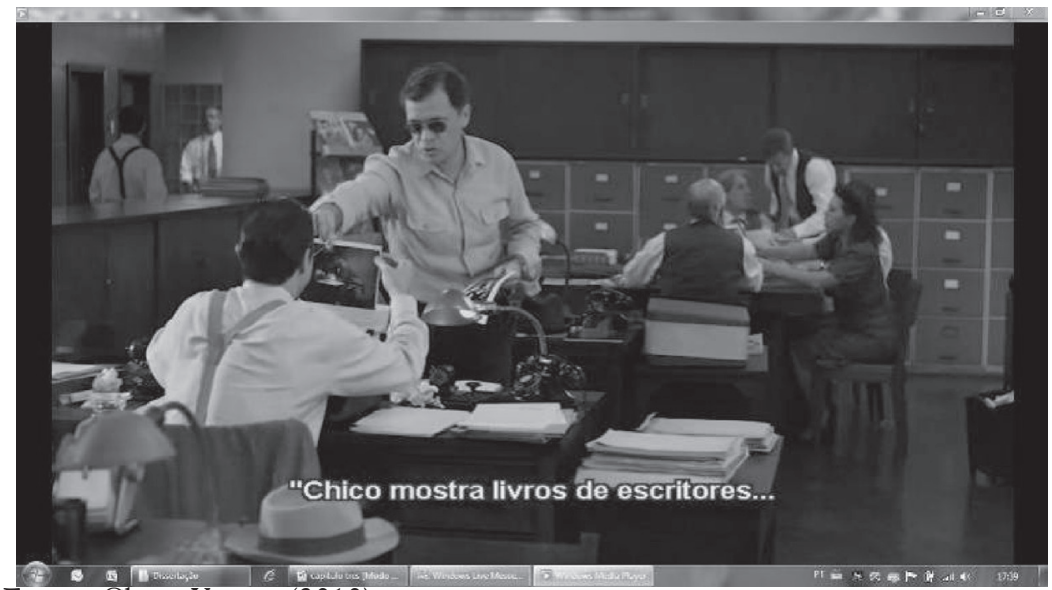

Fonte: Chico Xavier (2010).

Mais adiante, Chico Xavier lê a reportagem:

EXCERTO 9:

CX: - O senhor, leitor amigo, chegará ao fim destas linhas sem 
obter a resposta que há tanto tempo espera. É Chico Xavier um impostor ou não é? E dirá: dei 1500 por esta revista e não consegui desvendar o mistério? Sim, o mistério continuará por muito tempo. Ou, talvez, para sempre.

Figura $9^{2}-$ Revista com a reportagem sobre Chico Xavier

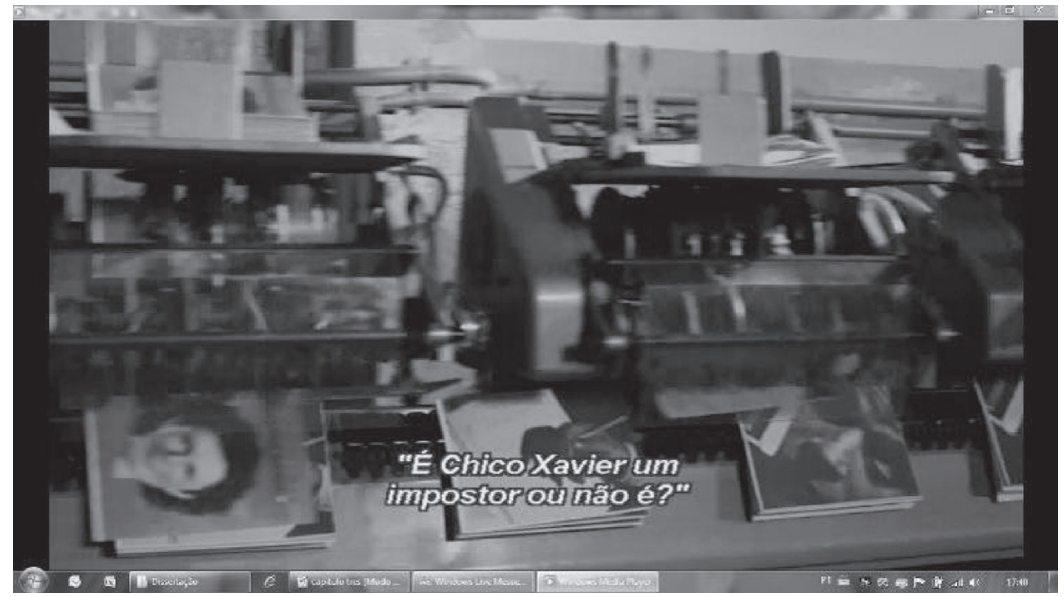

Fonte: Chico Xavier (2010).

A indústria cultural tem como objetivo inserir seus produtos no cotidiano dos consumidores, atingindo uma audiência cada vez maior. Para tanto, busca veicular entretenimento, diversão, de modo a satisfazer os gostos da grande massa. A perspectiva de um consumidor médio define os ingredientes que constituirão os bens da indústria cultural: ação, aventura, amor, o pitoresco, relações maniqueístas, o jogo, o culto às vedetes (MORIN, 1987), a inserção de personagens que instigam a curiosidade, como Chico Xavier.

Chico Xavier é transformado em celebridade na narrativa midiática e na vida real, sua figura está presente no cinema, em jornais e revistas, na TV e na internet, tal como esteve presente na revista $O$ Cruzeiro, conforme o trecho acima.

${ }^{2}$ Optamos pela figura que mostra a impressão da revista com o objetivo de enfatizar a indústria cultural. 
O excerto 10, a seguir, retrata Chico Xavier mais velho, quando sua mediunidade já era respeitada na sociedade brasileira.

EXCERTO 10:

Chico Xavier chega a Belo Horizonte e há uma multidão na rua esperando por ele. As pessoas acenam, aproximam-se do carro onde ele está. Querem tocá-lo, beijá-lo, em um movimento de adoração a um ídolo. Ele desce do carro e acena para o povo, pega na mão de algumas pessoas e entra, em meio à multidão, no Centro Espírita.

Figura 10 - Chico é tietado por uma multidão

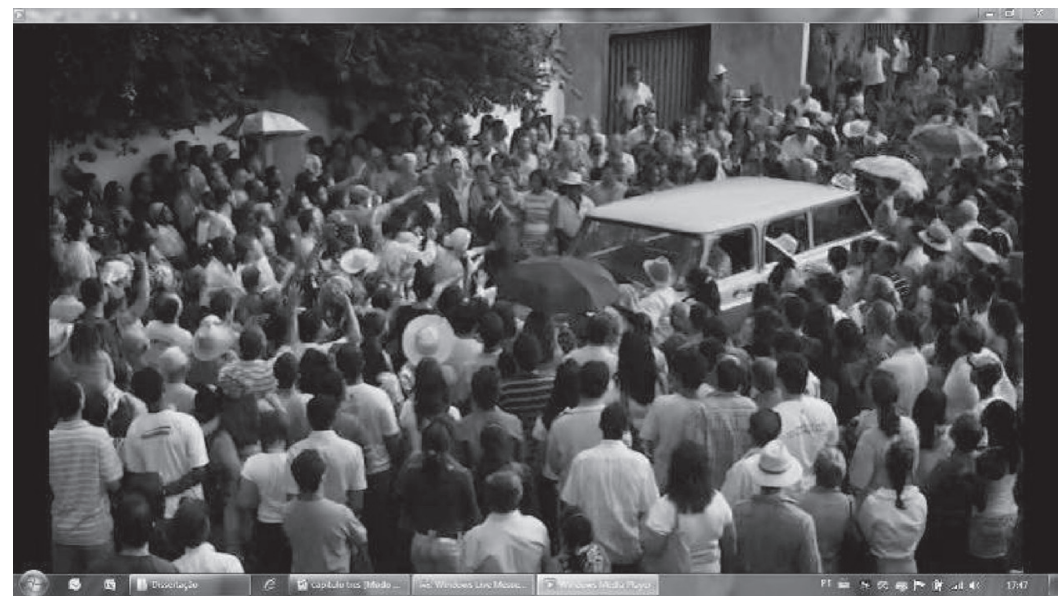

Fonte: Chico Xavier (2010).

No final do Programa Pinga-Fogo, Chico Xavier levanta-se e reza o Pai-Nosso com a plateia, de modo a envolvê-la completamente. Ao perceber o grande entrosamento entre Chico Xavier e o público, Orlando empenha-se em maximizar a cena:

EXCERTO 11:

O. - Manda o Saulo pedir pra ele psicografar, rápido.

SG: - Chico, eu quero lhe pedir um favor. Será que você poderia psicografar uma mensagem? 
CX: - Sim, sim. Como não?

Nesse momento, o próprio Orlando diz:

O: - Espetáculo completo!

CX pede música e psicografa, ao vivo, em rede nacional, em meio às câmeras, à plateia, aos entrevistadores e aos produtores do programa.

Figura 11 - Chico psicografa ao vivo no programa

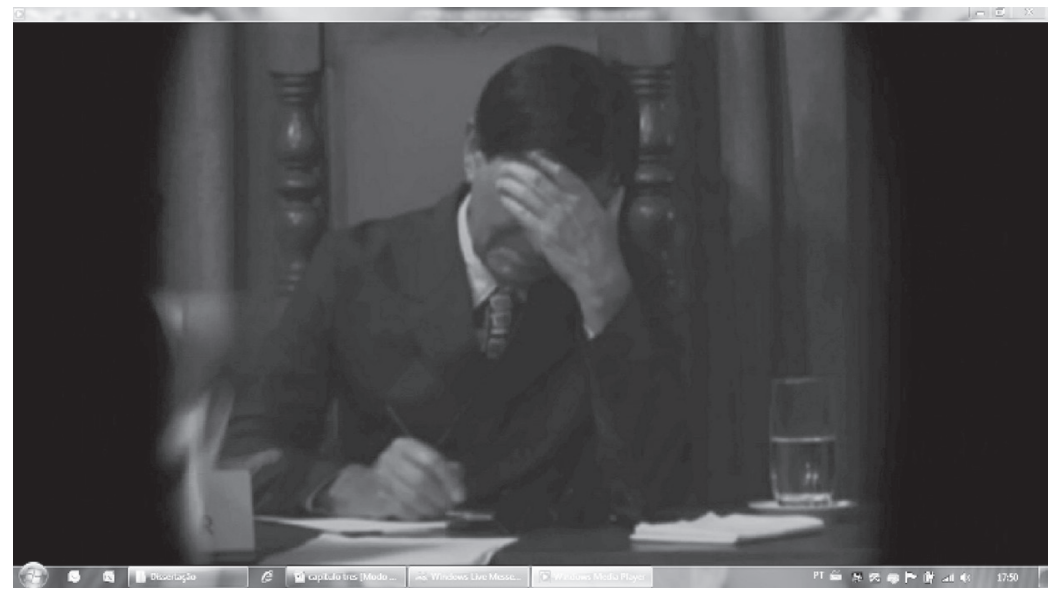

Fonte: Chico Xavier (2010).

A última fala de Orlando, destacada no trecho, pode ser considerada uma manifestação explícita da indústria cultural, que está conscientemente produzindo um espetáculo midiático. Não sendo bastantes as palavras do líder espírita em sua entrevista, os seus depoimentos, os organizadores do programa lançaram mão da imagem. O raciocínio presente nas palavras do médium cede lugar à emoção trazida pela imagem de sua ação de psicografar, de modo a convencer o telespectador. $\mathrm{O}$ que havia sido dito poderia, agora, ser visto e, de algum modo, sentido. $\mathrm{O}$ espetáculo, que deve encantar e acionar os sentidos (RUBIM, 2002), torna-se "completo".

Assim, no filme é possível perceber como Chico Xavier foi inserido na esfera do espetáculo ao longo de sua vida, como foi, aos poucos, ganhando espaço na mídia e se tornando um ícone. A 
partir da primeira aparição de Chico Xavier em um jornal, começa a ser criada uma celebridade, a princípio, em menor escala, dentro da própria cidade de Pedro Leopoldo, depois, do estado de Minas Gerais e, posteriormente, nos âmbitos nacional e internacional.

\section{Considerações finais}

processo de transformação de Chico Xavier em uma celebridade da sociedade midiática é representado no filme por uma dupla ficcionalidade, que explora tanto fatos da vida do médium, quanto sua participação no programa Pinga-fogo. $\mathrm{O}$ ápice de sua espetacularização consolida-se, na narrativa apresentada no filme, por sua participação no programa, "recheado" de emoções, sensacionalismo, provocações e idolatria.

O Programa Pinga-Fogo representa a consolidação de Chico Xavier como uma celebridade da sociedade do espetáculo e também explicita o protagonismo da mídia na representação do personagem no filme. Primeiramente porque a televisão é o espaço onde circulam os mais famosos artistas, políticos, jogadores de futebol. Ela pode ser considerada o espaço ocupado por aqueles que atingiram o auge da fama. E, em segundo lugar, pelos próprios recursos utilizados na apresentação do programa, como a exibição de fotos da vida e da família do médium e as palavras sensacionalistas utilizadas pelo entrevistador, que são elementos que têm como objetivo seduzir os telespectadores e causar neles um processo de identificação com o protagonista do espetáculo.

No Programa Pinga-Fogo, Chico Xavier poderia ter sido anunciado de forma mais isenta, sem a exibição de suas fotos, por exemplo. No entanto, não era esse o objetivo dos produtores do programa. Os objetivos do Pinga-Fogo, e quiçá, do filme Chico Xavier, eram, antes, inseri-lo na esfera do espetáculo, fazendo de sua figura e da doutrina Espírita, mais um produto da indústria cultural.

Também observamos outros elementos significativos da constituição do espetáculo na produção do filme, fortalecendo a representação de Chico Xavier como uma celebridade. A presença de olimpianos, de atores e atrizes famosos da Rede Globo, 
reforça o caráter espetaculoso do filme e alimenta o sincretismo realidade-ficção, conferindo credibilidade e emoção a essa narrativa midiática.

A autorreferencialidade é outro elemento, característico do espetáculo midiático, que pode ser observado na narrativa midiática Chico Xavier. A representação dos bastidores do Programa Pinga-Fogo possibilita-nos perceber como o espetáculo foi estrategicamente organizado. E há, ainda, o processo de sinergia midiática gerado na época do lançamento do filme. A narrativa midiática que conta a trajetória do herói Chico Xavier foi um assunto explorado em vários programas de TV, de diversos canais, na internet, em jornais e em revistas.

Uma das características do espetáculo é seu caráter público. Há uma relação entre espectador e corpo/objeto que se exibe, de modo que deve haver um desejo entre eles, ou seja, o público deve se interessar pelo evento exibido. $O$ principal artifício utilizado para despertar esse interesse é explorar a credibilidade do poder mediúnico de Chico Xavier, o que constitui um meio de aguçar a curiosidade do grande público, inserindo o médium na esfera do bem e do mal (será ele um impostor ou será verdadeiro?). A menção ao maniqueísmo intensifica o efeito atraente e sedutor do espetáculo e transforma seus personagens virtuosos em modelos de vida, em olimpianos, em heróis.

filme desperta-nos outra questão, que não foi objeto de estudo deste trabalho, mas que merece ser pensada em estudos futuros (nossos e/ou de outros pesquisadores). Para além do interesse lucrativo da indústria cultural, a quem interessaria a midiatização, a espetacularização de Chico Xavier? Seria interessante para a própria doutrina Espírita ou essa seria uma estratégia contrária aos seus preceitos (o que vem de encontro com a presença de atores reconhecidamente espíritas na filmografia analisada)? Tamanha espetacularização é contrária ao espírito de humildade e resignação que teve Chico Xavier ao longo de sua vida?

Cabe-nos, nos limites e propósitos deste artigo, apenas apontar que, embora tenha havido a consolidação da representação de Chico Xavier como um olimpiano da cultura de massa contemporânea, 
há peculiaridades quanto à recompensa/aos benefícios alcançados por ele. Apesar de ter se tornado um ícone, os benefícios que obteve são caracterizados pela renúncia aos bens materiais em favor do reconhecimento social da doutrina Espírita e da prática do amor ao próximo como princípio da existência humana. Isso em uma conjuntura social em que é fundamental que a espetacularização da realidade seja observada com rigor crítico, que permita distinguir os grandes homens de heróis de barro, fanaticamente idolatrados como bezerros de ouro.

\section{Referências}

ADORNO, Theodor W.; HORKHEIMER, Max. Dialética do Esclarecimento: fragmentos filosóficos. Tradução Guido Antônio de Almeida. Rio de Janeiro: Zahar, 1986. 254p.

ANDRADE. Ana Lúcia. O filme dentro do filme: a metalinguagem no cinema. Belo Horizonte. Ed. UFMG, 1999. 196 p.

AS MÃES de Chico Xavier. Direção de Glauber Filho; Halder Gomes. Produção de Luis Eduardo Girão. Brasil: Estação Luz Filmes; ATC Entretenimento; Lighthouse; Associação Estação da Luz, 2011. 1 DVD. (109 min.).

BAGDKIAN. Ben H. O Monopólio da mídia. São Paulo: Scritta Editorial, 1993. 294p.

CARVAlHO, Aline Torres Sousa. A representação de Chico Xavier como herói virtuoso: uma análise da narrativa midiática, 2011. Dissertação (Mestrado em Letras) - Universidade Federal de São João Del-Rei, São João del Rei.

CHICO XAVIER. Direção de Daniel Filho. Produção Daniel Filho. Brasil: Lereby; Globo Filmes; Estação da Luz, 2010. 1 DVD. (125 min.).

DEBORD, Guy. A Sociedade do espetáculo. São Paulo: Contraponto, 1997. 237p.

JACKOBSON, Roman. Linguística e Comunicação. 22 ed. Tradução Izidoro Blikstein; José Paulo Paes. São Paulo: Cultrix, 2010.162p.

LOCHARD, Guy; SOULAGES, Jean-Claude. Ritualisation visuelle de "Ciel mon mardi!". In. CHARAUDEAU, P. L'etude d'um genre televisuel: le "talk show" - Rapport scientifique des equipes du CAD. Paris: Université de Paris XIII, 1993, p. 145-160. 
MORIN, Edgar. Cultura de massa no século XX: $\mathrm{O}$ espírito do tempo 1 Neurose. 7. ed. Rio de Janeiro: Forense, 1987. 204p.

NOSSO LAR. Direção de Wagner de Assis. Produção Cinética Filmes. Coprodução: Migdal Filmes; Globo Filmes. Distribuição Fox Filme do Brasil. Roteiro e Direção Wagner de Assis. Produção executiva Luiz Augusto de Queiroz; Elisabeth Marinho Dias; Wagner de Assis, 2010. 1 DVD. (102 min.).

O FILME dos espíritos. Direção de André Marouço; Michel Dubret. Produção de Luiz Eduardo Girão. Produção Mundo Maior Filmes. Coprodução ATC Entretenimento; Lighthouse; Associação Estação da Luz, 2011. (101 min.).

REQUENA, Jesús G. El discurso televisivo: espectáculo de la postmodernidad. 4. ed. Madrid: Catedra, 1999. 167p.

RUBIM, Antônio A. C. Espetáculo, Política e Mídia. In: XI ENCONTRO ANUAL DA ASSOCIAÇÃ̃O NACIONAL DE PROGRAMAS DE PÓS- GRADUAÇÃO EM COMUNICAÇÃO (COMPÓS). Rio de Janeiro/RJ, jun. 2002. Anais... Disponível em: www.unb.br/comunicacaoepolitica/Albino2002. pdf. Acesso em: 18 out. 2009.

SGORLA, Fabiane, FOSSÁ, Maria Ivete Trevisan. Estratégias e operações de autoreferencialidade no Telejornalismo. In: VI Encontro Nacional de Pesquisadores em Jornalismo. Associação Brasileira de Pesquisadores em Jornalismo. São Paulo, 2008. Anais... p. 1-10.

\section{Aline Torres Sousa Carvalho}

Doutoranda em Estudos Linguísticos na Universidade Federal de Minas Gerais. É mestre em Letras: Teoria Literária e Crítica da Cultura, pela Universidade Federal de São João Del-Rei; especialista em Educação pela Universidade Federal de Lavras e graduada em Letras pela Universidade Federal de São João Del-Rei. Desenvolve estudos nas áreas de Comunicação e Análise do Discurso, destacando as Narrativas de Vida, tendo como projeto atual o estudo da narrativa de vida de Chico Xavier.

\section{Guilherme Jorge de Rezende}

Doutor em Comunicação pela Universidade Metodista de São Paulo. Mestre em Ciências da Comunicação pela ECA/USP e bacharel em Comunicação pela Universidade Federal de Minas Gerais. Autor do livro Telejornalismo no Brasil: um perfil editorial (2000). 